\title{
Effects of pure oxygen and reduced oxygen modified atmosphere packaging on the quality and microbial characteristics of fresh-cut pineapple
}

\author{
Yonggui Pan ${ }^{\star}$, Jiajia Zhu and and Shouying Li \\ College of Food Science, Hainan University, Haikou 570228, China
}

Received 13 July 2014 - Accepted 13 January 2015

\begin{abstract}
Introduction. Modified atmosphere packaging (MAP) is a preservation technique currently used by the fresh-cut fruit industry. Fruit quality may vary according to the concentration of oxygen $\left(\mathrm{O}_{2}\right)$ in the packaging. However, there is no published research on the effects of a pure $\mathrm{O}_{2}$ modified atmosphere in the packaging of fresh-cut pineapple. There are also no comparative studies of the differences between pure $\mathrm{O}_{2}$ and conventional low $\mathrm{O}_{2}$ MAP on the quality of fresh-cut pineapple. Materials and methods. Pineapple slices were sealed with a tray sealer using a polyethylene (PE) / polypropylene (PP) composite film and one of the following atmosphere treatments: $\left(4 \% \mathrm{O}_{2}+5 \%\right.$ $\left.\mathrm{CO}_{2}\right),\left(100 \% \mathrm{O}_{2}\right)$, and ambient air (control). We evaluated the effects on quality and microbial spoilage of fresh-cut pineapple. Results and discussion. Both modified atmosphere treatments delayed decreases in firmness, soluble solid contents (SSC), reducing sugar, and ascorbic acid. Pineapple slices packaged in pure $\mathrm{O}_{2}$ contained lower amounts of sugar and ascorbic acid and displayed more browning than the slices in the low $\mathrm{O}_{2}$ concentration. Additionally, both modified atmosphere treatments strongly delayed the growth of microorganisms. Aerobic bacteria, yeast and mold levels in pineapple slices packaged in pure $\mathrm{O}_{2}$ were higher than those packaged with the low $\mathrm{O}_{2}$ atmosphere during long-term storage. Conclusion. Modified atmosphere packaging using low $\mathrm{O}_{2}$ concentration $\left(4 \% \mathrm{O}_{2}+5 \% \mathrm{CO}_{2}\right)$ was better able to maintain the quality of fresh-cut pineapple than packaging with pure $\mathrm{O}_{2}$ atmosphere.
\end{abstract}

Keywords: pineapple / Ananas comosus / fresh-cut produce / controlled atmosphere packaging / food safety

Résumé - Effets du conditionnement sous atmosphère contrôlée, appauvrie ou enrichie en oxygène, sur la qualité et l'évolution microbienne de l'ananas fraîchement découpé. Introduction. Le conditionnement sous atmosphère modifiée (MAP) est une technique de conservation actuellement utilisée par l'industrie des fruits frais découpés. La qualité des fruits peut varier en fonction de la concentration en oxygène $\left(\mathrm{O}_{2}\right)$ dans l'emballage. Pourtant, rares sont les recherches publiées sur l'effet d'une atmosphère en $\mathrm{O}_{2}$ pur dans l'emballage d'ananas fraîchement découpé. De même, il n'existe aucune étude comparative des différences entre l'atmosphère en $\mathrm{O}_{2}$ pur et l'atmosphère classique basse en $\mathrm{O}_{2}$ sur la qualité de l'ananas fraîchement découpé. Matériel et méthodes. Des tranches d'ananas ont été scellées sous film plastique composite en polyéthylène $(\mathrm{PE}) /$ polypropylène $(\mathrm{PP})$ et soumis à l'une des conditions atmosphériques suivantes : faible oxygène $\left(4 \% \mathrm{O}_{2}+5 \% \mathrm{CO}_{2}\right)$, oxygène pur $\left(100 \% \mathrm{O}_{2}\right)$ et air ambiant (contrôle). Nous avons évalué les effets d'atmosphères modifiées sur la qualité et l'évolution microbienne d'ananas fraîchement découpé. Résultats et discussion. Les traitements d'atmosphère modifiée ont tous les deux retardé la baisse de fermeté, des teneurs en composés solubles (SSC), en sucres réducteurs et en acide ascorbique. Les tranches d'ananas emballées sous $\mathrm{O}_{2}$ pur ont produit des quantités plus faibles de sucre et d'acide ascorbique que les tranches d'ananas sous faible $\mathrm{O}_{2}$, mais l'ananas fraîchement coupé a montré davantage de signes de brunissement sous $\mathrm{O}_{2}$ pur. En outre, les traitements d'atmosphère modifiée ont fortement retardé la croissance des microorganismes. Les comptages de bactéries aérobies, de levures et de moisissures étaient plus nombreux dans les tranches d'ananas emballées sous $\mathrm{O}_{2}$ pur qu'en faible $\mathrm{O}_{2}$ sur une longue période de conservation. Conclusion. Le conditionnement sous atmosphère contrôlée utilisant une faible concentration d'oxygène $\left(4 \% \mathrm{O}_{2}+5 \%\right.$ de $\left.\mathrm{CO}_{2}\right)$ s'est révélée davantage en mesure de maintenir la qualité de l'ananas frais découpé que l'emballage sous $\mathrm{O}_{2}$ pur.

Mots clés : ananas / Ananas comosus / produit frais découpé / conditionnement sous atmosphère contrôlée / qualité des aliments.

^ Corresponding author: yongui 123@126.com 


\section{Introduction}

Fresh-cut pineapple (Ananas comosus (L.) Merr.) continues to increase in popularity because it is considered more convenient than the whole fruit [1]. However, current commercial fresh-cut pineapple products have a shelf-life of only 5-7 days at $1-7{ }^{\circ} \mathrm{C}$, limited largely by the development of off-flavors and off-odors from physiological processes and microbial spoilage $[2,3]$. At the same time, mechanical damage that occurs during fresh-cut processing also stimulates the generation of reactive oxygen species (ROS) including superoxide radicals $\left(\mathrm{O}_{2}^{-}\right)$, hydrogen peroxide $\left(\mathrm{H}_{2} \mathrm{O}_{2}\right)$, and hydroxyl radicals $(\mathrm{OH} \cdot)$ [4]. Immediately following wounding, a rapid increase in oxygen uptake is followed by an initial burst of ROS production [5]. Excess ROS can cause lipid peroxidation, membrane damage, and senescence of the fruit tissue [6].

Modified atmosphere packaging (MAP) is a preservation technique currently used by the fresh-cut produce industry [7]. MAP typically consists of a combination of low levels of $\mathrm{O}_{2}$ (2-6\%) and an elevated level of $\mathrm{CO}_{2}(7-15 \%)$. This mixture extends the shelf-life of fresh-cut pineapple by inhibiting fast-growing aerobes and slowing the respiration of living tissues $[8,9]$. Low levels of $\mathrm{O}_{2}$ and high levels of $\mathrm{CO}_{2}$ reduce tissue respiration rate, with the benefit of delaying senescence and extending the storage life of the fresh produce [10]. In our previous research, we found that $4 \% \mathrm{O}_{2}+5 \% \mathrm{CO}_{2}$ yielded better preservation effects for fresh-cut pineapple than ambient air. Product quality remained high after 9 days of storage at $10{ }^{\circ} \mathrm{C}$ [11]. However, it has been recognized that under certain conditions the growth of anaerobic psychrotrophic pathogens on fresh-cut produce might occur or even be stimulated by low-oxygen MAP [12]. In the last few years, high $\mathrm{O}_{2}$ MAP has been suggested as an alternative to low $\mathrm{O}_{2}$ atmospheres to inhibit the growth of naturally occurring spoilage microorganisms, prevent undesirable anoxic reparative processes, and maintain the high quality of fresh-cut produce [12-15]. Modified atmosphere with $50 \% \mathrm{O}_{2}+50 \% \mathrm{CO}_{2}$ inhibited the growth and volatile metabolite production of Candida argentea and $C$. sake on pineapple agar. It also retarded the growth of aerobes and yeasts on pineapple cubes during storage [16]. A MAP of $80-100 \% \mathrm{O}_{2}$ also inhibited the in vivo growth of Botrytis cinerea on strawberries [17]. Application of pure oxygen significantly prevented fruit pericarp browning and delayed the increase in membrane permeability of litchi fruit during storage [18]. Nevertheless, sensitivity to $\mathrm{O}_{2}$ toxicity varies between fruit species. Based on differences in browning times, we infer that increased $\mathrm{O}_{2}$ concentrations around and within fruits may result in higher levels of ROS, such as superoxides, hydrogen peroxides and hydroxyl radicals, that can damage plant tissues and cause premature senescence [19].

However, as far as we know, there are no published data on pure $\mathrm{O}_{2}$ modified atmospheres used for fresh-cut pineapple packaging. There are also no comparative studies of the differences between pure $\mathrm{O}_{2}$ and conventional low $\mathrm{O}_{2}$ concentrations on fresh-cut pineapple. The objective of this study was to evaluate the effect of a low oxygen MAP $\left(4 \% \mathrm{O}_{2}+5 \% \mathrm{CO}_{2}\right)$ and a pure oxygen MAP on the quality of fresh-cut pineapple during storage.

\section{Materials and methods}

\subsection{Plant material, treatments and storage}

Fresh pineapples (Ananas comosus (L.) Merr. cv 'Comte de Paris') were obtained from a local wholesale market and stored at $10 \pm 1{ }^{\circ} \mathrm{C}$ for $12 \mathrm{~h}$ before processing. The fruit was sorted to eliminate damaged or defective units and the selected pineapples were cleaned and the crowns removed. The pineapples in this experiment were at the 2-3 maturity stage according to the Dole pineapple color chart (between 25 and 50\% shell color change).

The pineapples were peeled, halved, cored, and sliced transversely $(3.0 \times 2.0 \times 1.5 \mathrm{~cm})$ using a sharp, stainless steel knife. The slices were then disinfected for $5 \mathrm{~min}$ in a $100 \mathrm{mg} \mathrm{L}^{-1}$ chlorine solution and dried. The knife and cutting board were washed with $100 \mathrm{mg} \mathrm{L}^{-1}$ chlorine solution for 5 min prior to use. They were divided into three subgroups, and individually sealed by a tray sealer $(20.5 \times 13.0 \times 3.0 \mathrm{~cm})$ using a polyethylene (PE)/ polypropylene (PP) composite film (0.045 $\mathrm{mm}$ thickness). The following modified atmosphere treatments were applied:

- group 1: low oxygen $\left(4 \% \mathrm{O}_{2}+5 \% \mathrm{CO}_{2}\right)$,

- group 2: pure oxygen $\left(100 \% \mathrm{O}_{2}\right)$,

- group 3: control at ambient air $\left(21 \% \mathrm{O}_{2}+0.03 \% \mathrm{CO}_{2}\right)$,

all balanced with $\mathrm{N}_{2}$ and stored at $10 \pm 0.3{ }^{\circ} \mathrm{C}$ with $80 \%$ relative humidity. Each group consisted of 30 trays of about $150 \mathrm{~g}$ pineapple slices. The atmosphere was supplied by a modified atmosphere packaging machine (MAP-H360, Suzhou Kaikang Machinery Equipment Co., Ltd., Suzhou, China).

\subsection{Gas analysis}

Gas composition inside packages was determined with an $\mathrm{O}_{2} / \mathrm{CO}_{2}$ Dual Head Space Analyzer (Model PAC CHECK 325, Mocon, Minneapolis, MN, USA).

\subsection{Quality evaluation}

Fruit samples were stored and analyzed at time points just before packaging (1 day) and after storage for 3, 5, 7, 9, and 11 days. At each time point, three trays per treatment were randomly chosen and analyzed.

Firmness of the slices was measured with a GY-1 Firmness Tester (Mudanjiang Mechanical Institute, Mudanjiang, China). Firmness was reported as the penetration force required to depress a $3.5 \mathrm{~mm}$ cylinder probe $10 \mathrm{~mm}$ into the sample. Color was measured with a CR-400 chromometer (Konica Minolta, Japan) and expressed as $\mathrm{L}^{*}, \mathrm{a}^{*}$, and $\mathrm{b}^{*}$, indicating luminance, chromaticity on a green (-) to red (+) axis, and chromaticity on a blue ( $(-)$ to yellow $(+)$ axis, respectively.

The content of reducing sugars was measured according to the methods of Han [20]. A 2 g sample of tissue was homogenized with distilled water and transferred to a $100 \mathrm{~mL}$ volumetric flask and brought up to volume with distilled water. The homogenate was extracted at room temperature for $20 \mathrm{~min}$ 
and then filtered. Ten $\mathrm{mL}$ filtrate was mixed with $2.5 \mathrm{~mL}$ of $0.1 \mathrm{~mol} \mathrm{~L}^{-1}$ iodine solution and $4.0 \mathrm{~mL}$ of $0.1 \mathrm{~mol} \mathrm{~L}^{-1}$ sodium hydroxide $(\mathrm{NaOH})$ in a conical flask. The conical flask was briefly shaken and placed in the dark for $15 \mathrm{~min}$. Then $1 \mathrm{~mL}$ of $0.5 \mathrm{~mol} \mathrm{~L}^{-1} \mathrm{HCl}$ was added and the solution was titrated with $0.1 \mathrm{~mol} \mathrm{~L}^{-1}$ sodium thiosulphate. When the solution became pale yellow, 5 drops of starch indicator were added, and the solution continued to be titrated until it was colorless.

Ascorbic acid content was measured by using the 2,6-dichlorophenol-indophenol dye titration method [20]. Pineapple samples $(1 \mathrm{~g})$ were homogenized with $50 \mathrm{~mL}$ of $2 \%(\mathrm{v} / \mathrm{v})$ oxalic acid. The mixture was then filtered for $15 \mathrm{~min}$. Ten $\mathrm{mL}$ filtrate were titrated against $0.01 \%(\mathrm{w} / \mathrm{v})$ 2,6-dichlorophenolindophenol dye that was standardized using an ascorbic acid standard. The ascorbic acid content was expressed as $\mathrm{mg} 100 \mathrm{~g}^{-1}$ fresh weight (FW).

Soluble solids content (SSC) was determined by extracting one drop of juice from the pineapple sample and measured with a digital refractometer (Atago Co. Ltd., WYT-1, Tokyo, Japan).

\subsection{Microbial analysis}

Aerobic bacterial counts, mold and yeast numbers were determined with a Film plate TM Aerobic count plate, and a Film plate TM mold \& yeast count plate (Guangzhou Oasis Biochemical Technology Co., Ltd., Guangzhou, China). A $1 \mathrm{~mm}$ thick layer of pineapple slice was removed with a sterilized stainless steel knife and a $1 \mathrm{~g}$ sample was ground with a sterilized mortar in an ultraclean laboratory. A 1:10 solution was prepared by mixing this sample with $9 \mathrm{~mL}$ sterilized saline. Then a 1:100 solution was prepared by pipetting $1 \mathrm{~mL}$ of the 1:10 solution into $9 \mathrm{~mL}$ of sterilized saline, and so on, to prepare a dilution series of the solution. The TM count film plate was placed on the sterile experiment table, the film was uncovered on the surface, and $1 \mathrm{~mL}$ solution was added to the plate. The film was covered gently and allowed to stand for $5 \mathrm{~min}$ until the solution dried. Two plates were inoculated for each dilution ratio. The plates were stacked (fewer than 12 plates per pile) and stored in their original plastic bags, with the film side upward. The bacterial plates were cultured for $24 \mathrm{~h}$ at $36 \pm 1{ }^{\circ} \mathrm{C}$ and the mold and yeast plates were cultured for $48-72 \mathrm{~h}$ at $29 \pm 1{ }^{\circ} \mathrm{C}$.

Colonies appeared red on the aerobic count plate and we counted the colony number by choosing a plate containing 10 to approximately 100 colonies. Mold and yeast appeared blue after growing on the plate. Mold colonies were radial and relatively large compared with round yeast colonies. We counted the colony number by choosing a plate that contains $10-100$ colonies. The colony numbers were counted as the film TM aerobic count plate manufacturer's instructions and expressed as colony forming units per gram fresh weight (cfu $\mathrm{g}^{-1} \mathrm{FW}$ ). Data from all colonization experiments were transformed with the $\log \mathrm{cfu}^{-1} \mathrm{FW}$ transformation.

\subsection{Statistical analysis}

All experiments were conducted in triplicate. All data points represent the mean \pm standard deviation (SD) of all
A

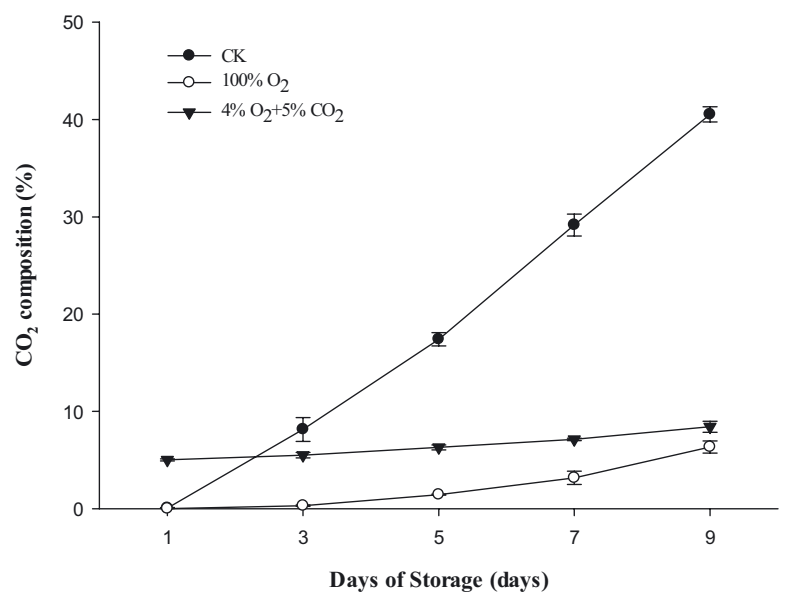

B

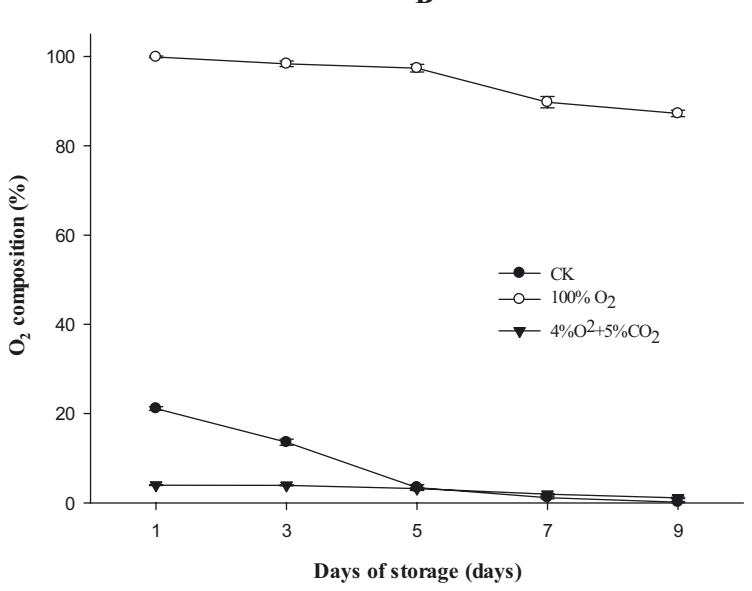

Figure 1. Evolution of $\mathrm{CO}_{2}(\mathrm{~A})$ and $\mathrm{O}_{2}(\mathrm{~B})$ concentrations measured in different MAP packaging of fresh-cut pineapple stored for 9 days at $10{ }^{\circ} \mathrm{C}(\mathrm{CK}$ : control at ambient air). Data presented are the means of three replicates. Vertical bars represent the SD.

replicates. One-way repeated measures and multivariate analysis of variance (ANOVA) of the general linear model for least significant differences (LSD) $P<0.05$ were performed using SPSS 17.0 (SPSS Inc., Chicago, IL, USA).

\section{Results and Discussion}

\subsection{Packaging atmosphere}

The $\mathrm{O}_{2}$ content decreased and $\mathrm{CO}_{2}$ content increased in fresh-cut pineapple kept in modified atmosphere packaging at $10{ }^{\circ} \mathrm{C}$ (figure 1). The $\mathrm{CO}_{2}$ concentration increased by $40.93 \%$ in air packs, whereas the $\mathrm{CO}_{2}$ concentration increased only $5-8 \%$ in the packs of $4 \% \mathrm{O}_{2}+5 \% \mathrm{CO}_{2}$. This increase in $\mathrm{CO}_{2}$ concentration was slightly lower than in the packs of $100 \% \mathrm{O}_{2}$. However, $\mathrm{O}_{2}$ concentration declined from $21 \%$ to $0.18 \%$ in air packs during the 9 day storage. The $\mathrm{O}_{2}$ concentration decreased only from $5 \%$ to $1.71 \%$ in the packs of $4 \% \mathrm{O}_{2}+5 \% \mathrm{CO}_{2} \cdot \mathrm{O}_{2}$ concentration in the packs of $100 \% \mathrm{O}_{2}$ 

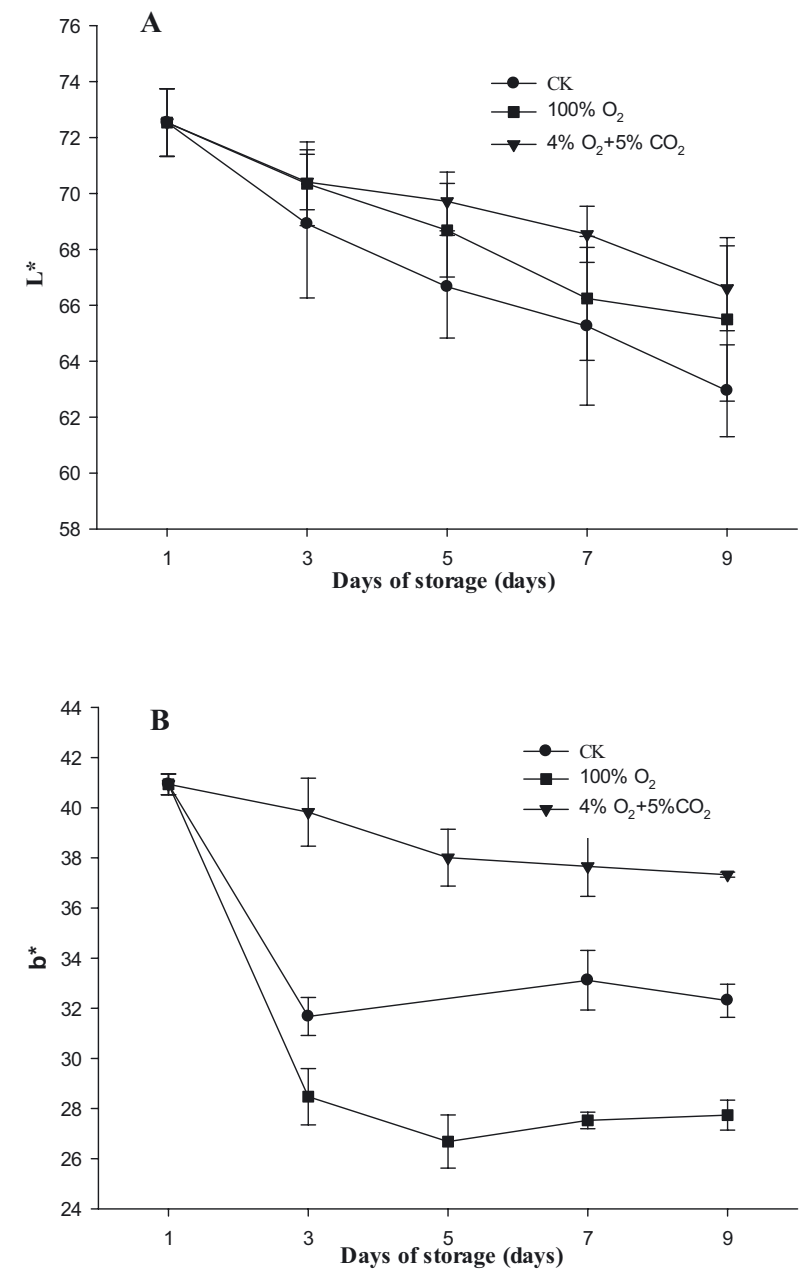

Figure 2. Evolution of (A) luminance $\left(\mathrm{L}^{*}\right)$ and $(\mathrm{B})$ chromaticity on a blue $(-)$ to yellow $(+)$ axis $\left(b^{*}\right)$ in different MAP packaging treatments of fresh-cut pineapple after 9 days of $10{ }^{\circ} \mathrm{C}$ storage (CK: control at ambient air). Data presented are the means of three replicates. Vertical bars represent the SD.

remained as high as $87.24 \%$ after 9 days. According to SolivaFortuny et al. [21], a decrease in $\mathrm{O}_{2}$ levels below a fermentative threshold limit of $2 \%$ could induce anaerobic respiration, which would result in the production of off-flavors and odors. We found that the control sample began to exhibit an alcoholic flavor within 5 days. At the same time, the oxygen concentration in these packages had dropped to $1.43 \%$. The change in gas composition in the MAPs is dependent on the plant tissue respiration [22]. Thus, our results indicate that MAPs with pure $\mathrm{O}_{2}$ and MAPs with low concentration of $\mathrm{O}_{2}(4 \%)$ and high concentration of $\mathrm{CO}_{2}(5 \%)$ were successful at inhibiting respiration in fresh-cut pineapple.

\subsection{Effect of MAP on the color of fresh-cut pineapple}

The color of fresh-cut pineapple was progressively browner during storage than that of just-cut pineapple for all the samples, as confirmed by luminosity decreases (figure 2 ).
This is a consequence of browning during storage [23-25], a phenomenon caused by phenolic oxidation, which is catalyzed by polyphenoloxidase enzymes to form colored melanins [26].

Compared with the control sample, the $100 \% \mathrm{O}_{2}$ samples and low $\mathrm{O}_{2}$-high $\mathrm{CO}_{2}$ significantly reduced decreases in luminance value during storage $(P<0.05)$. The luminance value reduction in pineapple slices in the low $\mathrm{O}_{2}$ MAP was the slowest (figure $2 A)$. The parameter of chromaticity on a blue (-) to yellow (+) axis decreased sharply after the first day of storage, but it showed a slight increase from 3 days to 5 days (in the ambient air and pure $\mathrm{O}_{2}$ groups) or a slow decline in the low $\mathrm{O}_{2}$ group $\left(4 \% \mathrm{O}_{2}+5 \% \mathrm{CO}_{2}\right.$ ) (figure $2 \mathrm{~B}$ ). As reported in previous studies, a slow decline in chromaticity could be due to the surface dehydration of the product that preludes tissue senescence [23]. During the storage process, the chromaticity on a blue ( $(-)$ to yellow (+) axis value of pineapple slices in low oxygen MAP experienced only a slight drop. However, the chromaticity of pineapple packaged in pure $\mathrm{O}_{2}$ declined the most.

On the one hand, our results show that a MAP with low concentrations of $\mathrm{O}_{2}(4 \%)$ combined with high concentrations of $\mathrm{CO}_{2}(5 \%)$ significantly reduced browning of fresh-cut pineapple. Similar results have also been reported by Marrero and Kader [27], who also found that reduced $\mathrm{O}_{2}$, with or without increased $\mathrm{CO}_{2}$, improved the retention of yellow color of fresh-cut pineapple. On the other hand, we also found that a MAP with pure $\mathrm{O}_{2}$ actually increased browning. High oxygen concentrations was also shown to be detrimental to the fruit quality of fresh-cut strawberries [28]. However, mushroom flesh and surfaces exposed to $80 \% \mathrm{O}_{2}$ were prevented from browning [29]. A similar result was also obtained by Limbo and Piergiovanni with potatoes [30]. Zheng et al. [31] and Duan et al. [18] also found that a high oxygen treatment reduced browning in loquat and litchi fruit respectively. Thus, the effects of a high oxygen MAP treatment on browning depends on the commodity, maturity, $\mathrm{O}_{2}$ concentration, and temperature.

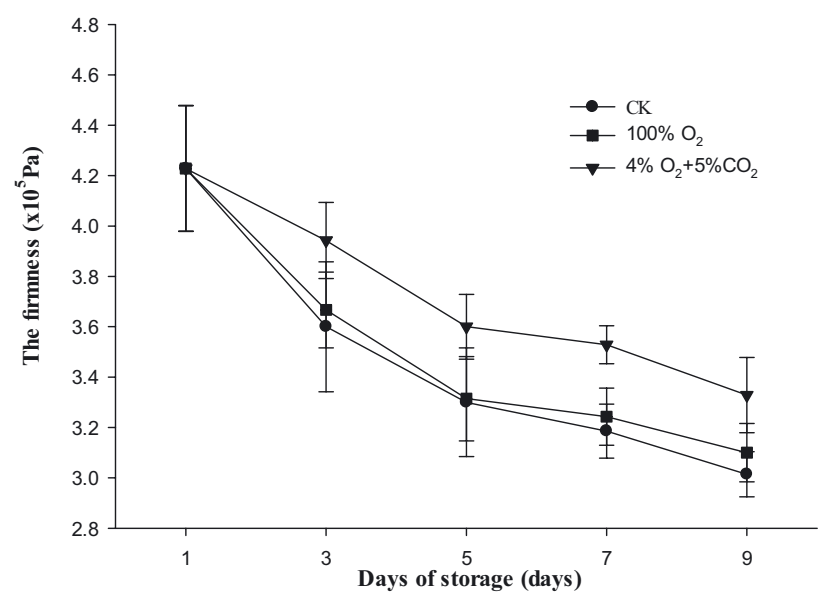

Figure 3. Change of firmness in different MAP packaging treatments of fresh-cut pineapple after 9 days of $10{ }^{\circ} \mathrm{C}$ storage (CK: control at ambient air). Data presented are the means of three replicates. Vertical bars represent the SD. 


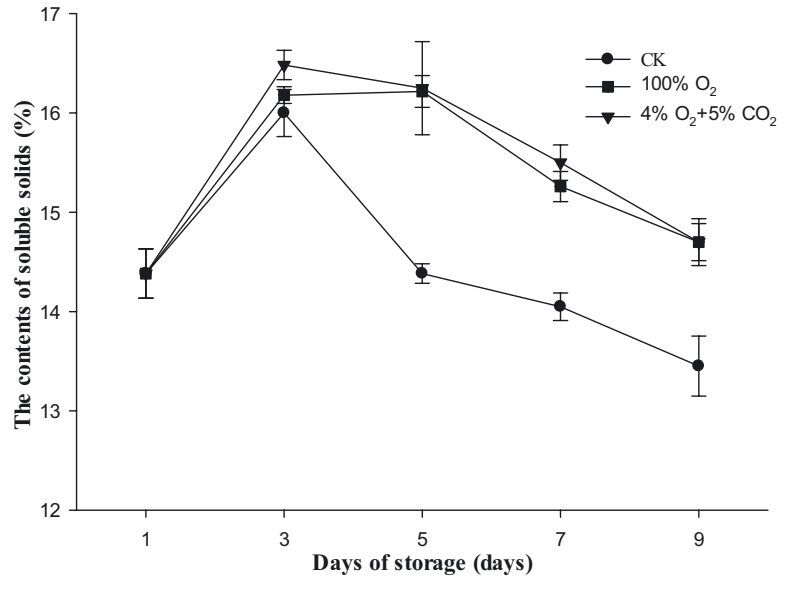

Figure 4. Change of soluble solid contents (SSC) in different MAP packaging treatments of fresh-cut pineapple after 9 days of $10{ }^{\circ} \mathrm{C}$ storage (CK: control at ambient air). Data presented are the means of three replicates. Vertical bars represent the SD.

\subsection{Effect of MAP on firmness of fresh-cut pineapple}

The firmness of the fresh-cut pineapple all showed a decreasing trend, but the slices packaged in ambient air and pure $\mathrm{O}_{2}$ decreased faster compared with firmness in the samples packaged in $4 \% \mathrm{O}_{2}+5 \% \mathrm{CO}_{2}$ (figure 3). Further statistical analysis showed no significant differences $(P<0.05)$ between the pure $\mathrm{O}_{2}$ and control ambient air packaged pineapple. Fernández-León et al. [32] also found $10 \% \mathrm{O}_{2}$ and $5 \%$ $\mathrm{CO}_{2}$ delayed firmness decrease of broccoli crowns.

\subsection{Effect of MAP on nutrition quality of fresh-cut pineapple}

All pineapple MAP packaging treatments exhibited a downward trend after an initial increase in SSC (figure 4). The SSC in the slices packaged in pure $\mathrm{O}_{2}$ and $4 \% \mathrm{O}_{2}+5 \% \mathrm{CO}_{2}$ was significantly lower than the control group. There was no significant difference $(P<0.05)$ between the pure $\mathrm{O}_{2}$ and $4 \%$ $\mathrm{O}_{2}+5 \% \mathrm{CO}_{2}$ groups. The rise of SSC in the early stage of storage was surprising but the following decline due to respiratory consumption occurred as expected. Santos et al. [33] also found that fresh-cut "Pérola" pineapple retained higher values of SSC under a $5 \% \mathrm{O}_{2}+5 \% \mathrm{CO}_{2}$ modified atmosphere. In contrast, Montero-Calderón et al. [34] found that SSC values showed little change in fresh-cut pineapple (Ananas comosus) during storage and no significant differences were found over time or among packaging conditions. Similar results have also been reported in fresh-cut pineapple ('Gold' cultivar) stored under modified atmosphere conditions of $2 \% \mathrm{O}_{2}$ and $10 \%$ $\mathrm{CO}_{2}$ [35].

Sugar is one of the main nutrients in the pineapple fruit. As illustrated in figure 5, all of the pineapple groups showed a downward trend in sugar content. However, pineapple packaged in modified atmospheres had a slower decline in sugar than the pineapple slices packaged in ambient air. The sugar content in pineapple packaged in $4 \% \mathrm{O}_{2}+5 \% \mathrm{CO}_{2}$ declined

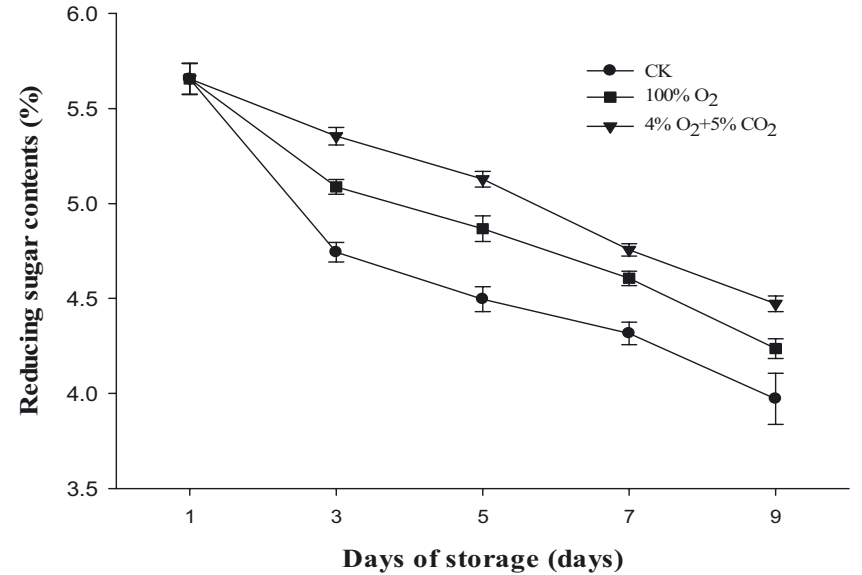

Figure 5. Change of reducing sugar content in different MAP packaging treatments of fresh-cut pineapple after 9 days of $10{ }^{\circ} \mathrm{C}$ storage (CK: control at ambient air). Data presented are the means of three replicates. Vertical bars represent the SD.

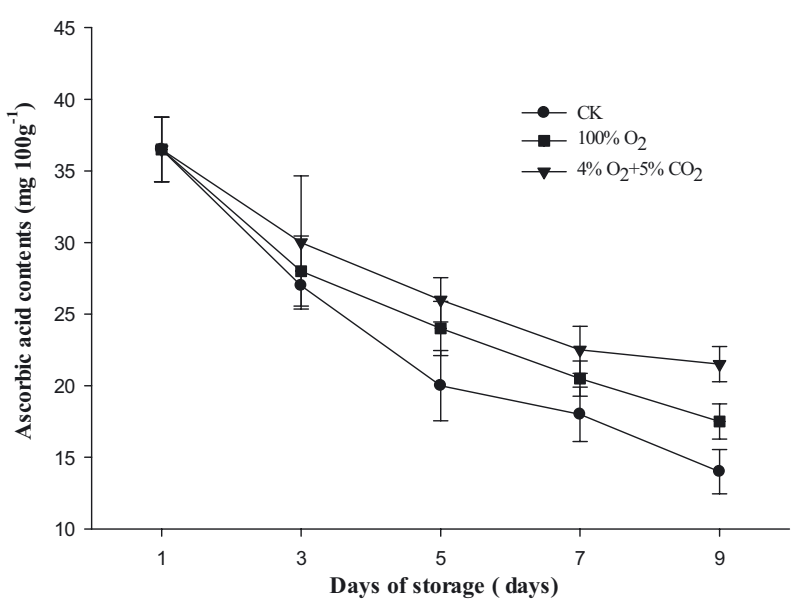

Figure 6. Change of ascorbic acid in different MAP packaging treatments of fresh-cut pineapple after 9 days of $10{ }^{\circ} \mathrm{C}$ storage (CK: control at ambient air). Data presented are the means of three replicates. Vertical bars represent the SD.

most slowly. Between the first measurement and the end of the storage time, the sugar content of the ambient air control group, the pure oxygen MAP group and the low $\mathrm{O}_{2}$ group fell to $27.2 \%, 24.6 \%$ and $17.5 \%$, respectively.

The content of ascorbic acid (AA) of fresh-cut pineapple decreased in all samples during the course of the study (figure 6). However, pure $\mathrm{O}_{2}$ and low $\mathrm{O}_{2}$ modified atmospheres both slowed the decline of AA content. The low $\mathrm{O}_{2}$ MAP was most effective. A similar result was found in broccoli [36]. The magnitude of these changes may be directly related to the $\mathrm{O}_{2}$ concentration inside the packages, as reported by Soliva-Fortuny et al. [37]. Hence, higher concentrations of $\mathrm{O}_{2}$ in the bag headspace results in larger decreases in AA. The reason for this relationship between AA content and $\mathrm{O}_{2}$ level in MAP needs further research. 


\subsection{Effect of MAP on microbial stability in fresh-cut pineapple}

Aerobic bacterial counts can reflect the freshness of the produce and the hygienic conditions of the fresh-cut production facility. As illustrated in figure 7A, the aerobic bacterial count in pineapple slices packaged in pure $\mathrm{O}_{2}$ and those packaged in low concentration $\mathrm{O}_{2}$ only reached 3.9 and $4.5 \mathrm{log} \mathrm{cfu} \mathrm{g}^{-1}$ respectively, while slices packaged in ambient air reached $5.9 \log \mathrm{cfu} \mathrm{g}^{-1}$ by the end of the storage time. This result suggests that a conventional MAP $\left(4 \% \mathrm{O}_{2}+5 \% \mathrm{CO}_{2}\right)$ and a super atmospheric $\mathrm{O}_{2} \mathrm{MAP}$ both contribute to inhibiting the growth of microorganisms. Similar results have also been reported by Oms-Oliu et al. [38], who found that both $(2.5 \mathrm{kPa}$ $\left.\mathrm{O}_{2}+7 \mathrm{kPa} \mathrm{CO} 2\right)$ and $\left(70 \mathrm{kPa} \mathrm{O}_{2}\right)$ atmospheres significantly reduced the growth of microorganisms in fresh-cut melon. In addition, low $\mathrm{O}_{2}$ and moderate $\mathrm{CO}_{2}$ atmospheres can slightly reduce the microbial growth of fresh-cut cantaloupe and honeydew melons [39]. Fifty percent $\mathrm{O}_{2}$ combined with $50 \% \mathrm{CO}_{2}$ also decreased the growth of aerobes on pineapple cubes during storage [16].

The growth of yeasts and molds was also markedly decreased on pineapple slices packaged in pure $\mathrm{O}_{2}$ and those packaged in low concentration $\mathrm{O}_{2}$ modified atmospheres ( $f$ igure $7 B, 7 C$ ). By the end of the storage time (day 9), the slices packaged in low concentration $\mathrm{O}_{2}$ had the lowest mold and yeast growth, followed by those packaged in pure $\mathrm{O}_{2}$. Slices packaged in ambient air experienced the highest mold and yeast growth. In agreement with our results, Oms-Oliu et al. [38] also found that yeast and mould growth on fresh-cut melon stored under $(2.5 \mathrm{kPa} \mathrm{O}+7 \mathrm{kPa} \mathrm{CO} 2)$ or $\left(70 \mathrm{kPa} \mathrm{O}_{2}\right)$ atmospheres were inhibited until the third week of storage.

On the other hand, high oxygen concentration has been reported to stimulate the growth of microorganisms on freshcut fruit and vegetables [40]. Enterobacteria on sliced carrots were inhibited under $50 \% \mathrm{O}_{2}+30 \% \mathrm{CO}_{2}$, but stimulated under 80 or $90 \% \mathrm{O}_{2}$. Poubol and Izumi [41] also reported that a high $\mathrm{O}_{2}$ of $60 \mathrm{kPa}$ stimulated the growth of aerobic bacteria on "Carabao" mango cubes and yeasts on 'Nam Dokmai' mango cubes at $13{ }^{\circ} \mathrm{C}$. In their opinion, stimulated growth of bacteria under high $\mathrm{O}_{2}$ may be influenced by the $\mathrm{pH}$ of the fruit surface [41].

Other research has shown that high oxygen has no effect on microbial growth. Growth of yeasts and anaerobic mesophilic bacteria was not affected by varying oxygen during the packaging of mushroom slices [42]. The effects of high oxygen on microorganism growth may be related to the microbial species present and the food substrate.

\section{Conclusions}

The major factors that shorten the shelf life of fresh-cut pineapple are those that increase fruit deterioration and make the fruit vulnerable to infection by microorganisms. MAP using low oxygen $\left(4 \% \mathrm{O}_{2}+5 \% \mathrm{CO}_{2}\right)$ and pure oxygen both delayed the decrease of firmness, SSC, reducing sugars, and AA in fresh-cut pineapple. However, MAP using pure $\mathrm{O}_{2}$ exhibited a faster decline of sugar and AA. Furthermore, MAP
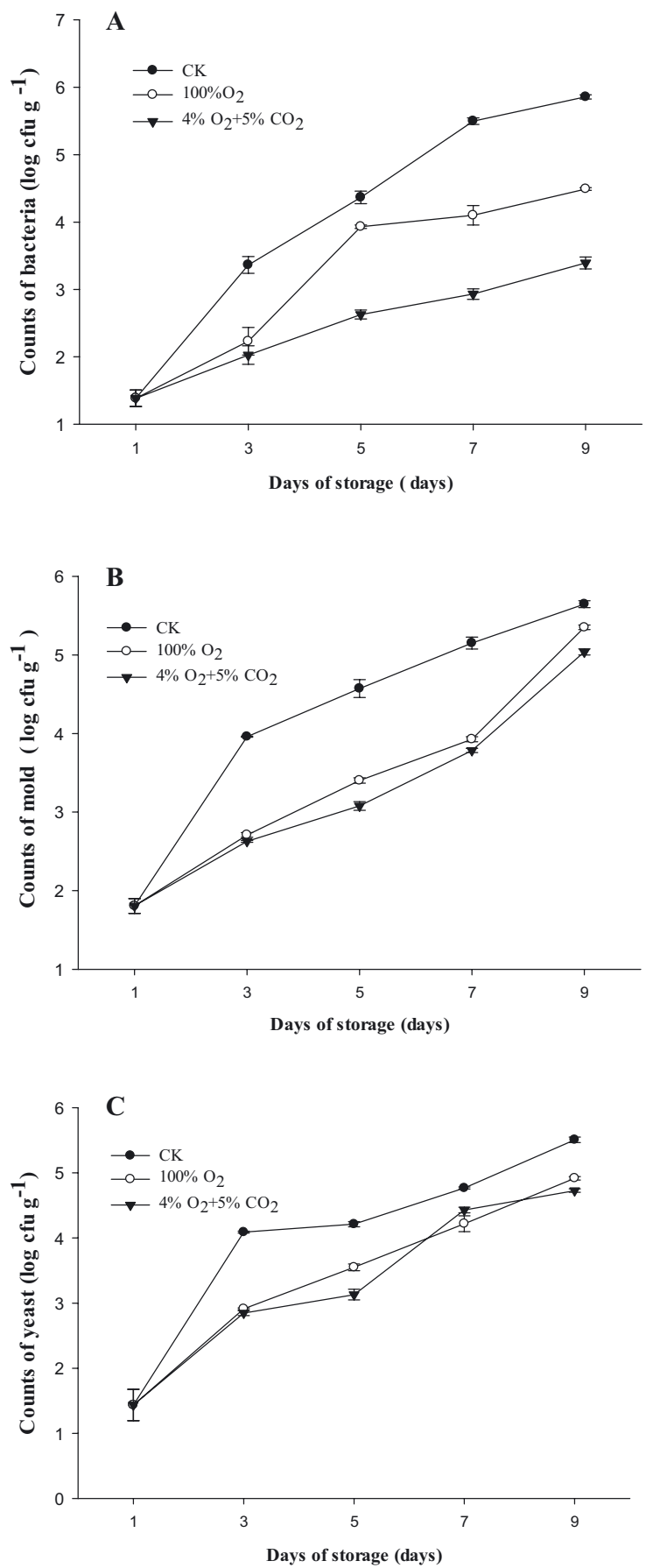

Figure 7. Changes of (A) aerobic bacterial (B) mold, and (C) yeast counts in different MAP packaging treatments of fresh-cut pineapple after 9 days of $10{ }^{\circ} \mathrm{C}$ storage (CK: control at ambient air). Data presented are the means of three replicates. Vertical bars represent the SD.

using pure $\mathrm{O}_{2}$ increased browning of the fresh-cut pineapple. Both MAP treatments strongly decreased the aerobic bacterial count and decreased the growth of yeasts and mold. However, pineapple slices packaged in pure $\mathrm{O}_{2}$ had higher aerobic bacterial counts and more yeasts and mold than those packaged in low $\mathrm{O}_{2}$ concentrations $\left(4 \% \mathrm{O}_{2}+5 \% \mathrm{CO}_{2}\right)$. Overall, the use of MAPs with conventional low $\mathrm{O}_{2}$ concentrations is 
more effective for maintaining the quality of fresh-cut pineapple than MAPs using pure $\mathrm{O}_{2}$.

Acknowledgements. This project was co-supported by the Special Fund for Agro-scientific Research in the Public Interest (201203021).

\section{References}

[1] Bierhals V.S., Chiumarelli M., Hubinger M.D., Effect of cassava starch coating on quality and shelf life of fresh-cut pineapple (Ananas comosus L. Merril cv "Perola"), J. Food Sci. 76 (2011) E62-E72.

[2] Liu C.L., Hsu C.K., Hsu M.M., Improving the quality of fresh-cut pineapples with ascorbic acid/sucrose pretreatment and modified atmosphere packaging, Packag. Technol. Sci. 20 (2007) 337-343.

[3] Montero-Calderón M., Rojas-Graü M.A.A., Aguilo-Aguayo I., Soliva-Fortuny R., Martin-Belloso O., Influence of modified atmosphere packaging on volatile compounds and physicochemical and antioxidant attributes of fresh-cut pineapple (Ananas comosus), J. Agr. Food Chem. 58 (2010) 5042-5049.

[4] Galindo F.G., Sjöholm I., Rasmusson A.G., Widell S., Kaack K., Plant stress physiology: opportunities and challenges for the food industry, Crit. Rev. Food Sci. Nutr. 47 (2007) 749-763.

[5] Bolwell G.P., Butt V.S., Davies D.R., Zimmerlin A., The origin of the oxidative burst in plants, Free Radical Res. 23 (1995) 517-532.

[6] Yang H., Wu F., Cheng J., Reduced chilling injury in cucumber by nitric oxide and the antioxidant response, Food Chem. 127 (2011) 1237-1242.

[7] Rico D., Martín-Diana A.B., Barat J.M., Barry-Ryan C., Extending and measuring the quality of fresh-cut fruit and vegetables: a review, Trends Food Sci. Technol. 18 (2007) 373-386.

[8] Sandhya, Modified atmosphere packaging of fresh produce: Current status and future needs, LWT - Food Sci. Technol. 43 (2010) 381-392.

[9] Martínez-Ferrer M., Harper C., Pérez-Muntoz F., Chaparro M., Modified atmosphere packaging of minimally processed mango and pineapple fruits, J. Food Sci. 67 (2002) 3365-3371.

[10] Saltveit M.E., A summary of CA requirements and recommendations for vegetables, VIII International Controlled Atmosphere Research Conference 600, 2001.

[11] Zhu J.J., Pan Y.G., Influence od modified atmosphereh packaging on quality in fresh-cut pineapple, Food Res. Develop. 33 (2012) 185-187.

[12] Rojas-Graü M.A., Oms-Oliu G., Soliva-Fortuny R., MartínBelloso O., The use of packaging techniques to maintain freshness in fresh-cut fruits and vegetables: a review, Int. J. Food Sci. Technol. 44 (2009) 875-889.

[13] Day B., High oxygen modified atmosphere packaging for fresh prepared produce, Postharvest News Inform. 7 (1996) 31-34.

[14] Day B., Novel MAP for freshly prepared fruit and vegetable products, Postharvest News Inform. 11 (2000) 27-31.

[15] Oms-Oliu G., Soliva-Fortuny R., Martin-Belloso O., Modeling changes of headspace gas concentrations to describe the respiration of fresh-cut melon under low or superatmospheric oxygen atmospheres, J. Food Eng. 85 (2008) 401-409.

[16] Zhang B.Y., Samapundo S., Pothakos V., de Baenst I., Sürengil G., Noseda B., Devlieghere F., Effect of atmospheres combining high oxygen and carbon dioxide levels on microbial spoilage and sensory quality of fresh-cut pineapple, Postharvest Biol. Technol. 86 (2013) 73-84.
[17] Wszelaki A.L., Mitcham E.J., Elevated oxygen atmospheres as a decay control alternative on strawberry, HortSci. 34 (1999) $514-515$

[18] Duan X., Liu T., Zhang D., Su X., Lin H., Jiang Y., Effect of pure oxygen atmosphere on antioxidant enzyme and antioxidant activity of harvested litchi fruit during storage, Food Res. Int. 44 (2011) 1905-1911.

[19] Fridovich I., Biological effects of the superoxide radical, Arch Biochem Biophys. 247 (1986) 1-11.

[20] Han Y.S., Food chemistry experiment guidance, China Agricultural University Press, Beijing, 1996.

[21] Soliva-Fortuny R.C., Elez-Martıìnez P., Martı̀n-Belloso O., Microbiological and biochemical stability of fresh-cut apples preserved by modified atmosphere packaging, Innov. Food Sci. Emerg. Technol. 5 (2004) 215-224.

[22] Wang C.T., Wang C.T., Cao Y.P., Robert Nout M.J., Sun B.G., Liu L., Effect of modified atmosphere packaging (MAP) with low and superatmospheric oxygen on the quality and antioxidant enzyme system of golden needle mushrooms (Flammulina velutipes) during postharvest storage, Eur. Food Res. Technol. 232 (2011) 851-860.

[23] González-Aguilar G.A., Ruiz-Cruz S., Cruz-Valenzuela R., Rodríguez-Félix A., Wang C.Y., Physiological and quality changes of fresh-cut pineapple treated with antibrowning agents, LWT - Food Sci. Technol. 37 (2004) 369-376.

[24] Antoniolli L.R., Benedetti B.C., Sigrist J.M.M., Silveira N.F.A., Quality evaluation of fresh-cut Pérola pineapple stored in controlled atmosphere, Food Sci. Technol. (Campinas) 27 (2007) 530-534.

[25] Rocculi P., Cocci, E., Romani, S., Sacchetti, G., Rosa, M.D., Effect of 1-MCP treatment and $\mathrm{N}_{2} \mathrm{O}$ MAP on physiological and quality changes of fresh-cut pineapple, Postharvest Biol. Technol. 51 (2009) 371-377.

[26] Budu A., Joyce D., Effect of 1-methylcyclopropene on the quality of minimally processed pineapple fruit, Anim. Prod. Sci. 43 (2003) 177-184.

[27] Marrero A., Kader A.A., Optimal temperature and modified atmosphere for keeping quality of fresh-cut pineapples, Postharvest Biol. Technol. 39 (2006) 163-168.

[28] Wszelaki A., Mitcham E., Effects of superatmospheric oxygen on strawberry fruit quality and decay, Postharvest Biol. Technol. 20 (2000) 125-133.

[29] Liu Z., Wang X., Changes in color, antioxidant, and free radical scavenging enzyme activity of mushrooms under high oxygen modified atmospheres, Postharvest Biol. Technol. 69 (2012) $1-6$.

[30] Limbo S., Piergiovanni L., Shelf life of minimally processed potatoes: Part 1. Effects of high oxygen partial pressures in combination with ascorbic and citric acids on enzymatic browning, Postharvest Biol. Technol. 39 (2006) 254-264.

[31] Zheng Y., Su X., Li Q., Li S., Xi Y., Effect of high oxygen on respiration rate, polyphenol oxidase activity and quality in postharvest loquat fruits, Plant Physiol. Commun. 36 (2000) 318-320.

[32] Fernández-León M.F., Fernández-León A.M., Lozano M., Ayuso M.C., González-Gómez D., Different postharvest strategies to preserve broccoli quality during storage and shelf life: Controlled atmosphere and 1-MCP, Food Chem. 138 (2013) 564-573. 
[33] Santos J.C.B., Boas, V., de Barros E.V., Prado M.E.T., Pinheiro A.C.M., Evaluation of quality in fresh-cut "Pérola" pineapple stored under modified atmosphere, Ciêne. Agrotec. 29 (2005) 353-361.

[34] Montero-Calderón M., Rojas-Graü M.A., Martín-Belloso O., Effect of packaging conditions on quality and shelf-life of freshcut pineapple (Ananas comosus), Postharvest Biol. Technol. 50 (2008) 182-189.

[35] Gil M.I., Aguayo E., Kader A.A., Quality changes and nutrient retention in fresh-cut versus whole fruits during storage, J. Agr. Food Chem. 54 (2006) 4284-4296.

[36] Fernández-León M.F., Fernández-León A.M., Lozano M., Ayuso M.C., González-Gómez D., Altered commercial controlled atmosphere storage conditions for "Parhenon" broccoli plants (Brassica oleracea L. var. italica). Influence on the outer quality parameters and on the health-promoting compounds, LWT - Food Sci. Technol. 50 (2013) 665-672.

[37] Soliva-Fortuny R., Oms-Oliu G., Martín-Belloso O., Effects of ripeness stages on the storage atmosphere, color, and textural properties of minimally processed apple slices, J. Food Sci. 67 (2002) 1958-1963.
[38] Raybaudi-Massilia Martínez R.M., Soliva-Fortuny R., MartínBelloso O., Effect of superatmospheric and low oxygen modified atmospheres on shelf-life extension of fresh-cut melon, Food Control. 19 (2008) 191-199.

[39] Bai J., Saftner R.A., Watada A.E., Characteristics of fresh-cut honeydew (Cucumis melo L.) available to processors in winter and summer and its quality maintenance by modified atmosphere packaging, Postharvest Biol. Technol. 28 (2003) 349359.

[40] Amanatidou A., Slump R., Gorris L., Smid E. High oxygen and high carbon dioxide modified atmospheres for shelf-life extension of minimally processed carrots, J. Food Sci. 65 (2000) 6166.

[41] Poubol J., Izumi H., Physiology and microbiological quality of fresh-cut mango cubes as affected by high- $\mathrm{O}_{2}$ controlled atmospheres, J. Food Sci. 70 (2005) m286-m291.

[42] Jacxsens L., Devlieghere F., Van der Steen C., Debevere J., Effect of high oxygen modified atmosphere packaging on microbial growth and sensorial qualities of fresh-cut produce, Int. J. Food Microbiol. 71 (2001) 197-210.

Cite this article as: Yonggui Pan, Jiajia Zhu, and Shouying Li. Effects of pure oxygen and reduced oxygen modified atmosphere packaging on the quality and microbial characteristics of fresh-cut pineapple. Fruits 70 (2015) 101-108. 